\title{
Bioeconomy and green economy: European strategies, action plans and impact on life quality
}

\author{
Carmen SOCACIU ${ }^{1,2}$ \\ ${ }^{1)}$ Department of Biochemistry, University of Agricultural Sciences and Veterinary Medicine Cluj-Napoca, Romania; \\ ${ }^{2)}$ CCD-BIODIATECH, Proplanta RTD Centre, Cluj-Napoca, Romania \\ e-mail: carmen.socaciu@usamvcluj.ro
}

Bulletin UASVM Food Science and Technology 71(1) / 2014

ISSN-L 2344-2344; Print ISSN 2344-2344; Electronic ISSN 2344-5300

\begin{abstract}
The review presents the definitions, the main concepts and vision for Bioeconomy versus Green economy. The key aspects which are discussed refers to European strategy and action plans (1), Bioeconomy and agriculture orientation (2), Biorefinery for a better life quality (3) and involvement of education, research and innovation for the progress of Bioeconomy (4). There are described the main challenges, requirements, aims related to the integration of bioeconomy in different economic sectors, the strategic plans and activities at global level with specific consideration for European member states. Innovation and the need of an integrative knowledge, creating translational bridges and covering gaps by sustainable interdisciplinary research and technology development are also discussed. Considering the vital links betweeen research - innovation and technlogy transfer, for the bioeconomy progress, relevant examples will be presented, related to European programs (2014-2020), e.g. Horizon 2020, European Innovation partnership (EIP) and Partnerships Public-Private (PPP). The role of universities, as best providers of education and research will be underlined with a strong focus on the need to develop the entrepreunership culture and their role as knowledge and innovation disseminator, filling the gap research-invention-innovation.
\end{abstract}

Keywords: bioeconomy, green economy, EU strategy, Horizon 2020, biorefinery, education and research, innovation.

\section{INTRODUCTION}

Bioeconomy versus Green economy: concepts and vision. The bioeconomy concept represents „a vision for the future society” to become less dependent on fosil resources and to provide energy and added-value products (foodfeed-fibers, industrial and health products) by a sustainable use of bioresources. Bioeconomy definition, as defined in EU documents, means the "production of renewable biological resources (biomass) and their conversion to food, feed, bio-based products and bioenergy" (European Commission, 2005, 2011, 2012, 2013; Trigo et al., 2013). Renewable biomass encompasses any biological material (agriculture, forestry and animal-based including fish) as a product itself or used as raw material. The assessment of existing socio-economic principles, criteria and indicators for biomass production and conversion was recently reviewed (Diaz-Chave Rocio A, 2010).

The large technological areas included in the bioeconomy concept are: agriculture, forestry, fisheries, food and pulp/paper production, as well biotechnology, chemical and energy industries (European Commission, 2012). Nowadays, bioeconomy has an annual turnover of about 2 trillion EURO and employs more than 22 million people ( $9 \%$ of total EU workforce).

The four pillars of Bioeconomy are: Food production and processing (1), Value-added food and health products (2), Agri-environmental products and services (3) and Energy and bio- 
processing (4). These pillars need sustainable bridges between different sectors and ares, as described below (Fig. 1) (www.biofuelstp.eu/ bioeconomy).

A complex picture of the biological systems contributing to bioeconomy development as well the responses, demands and impacts of bioeconomy are presented in Figure 2.
The mature and sustainable Bioeconomy, under development worldwide, must offer global food security, improved nutrition and health, to create smart bio-based products and biofuels, to help agriculture, forestry, aquaculture and other ecosystems to adapt to climate change.

Green economy driven by the " $3 \mathrm{~F}$ " crisis (Food-Feed-Fibers) is defined as a part of the inte-

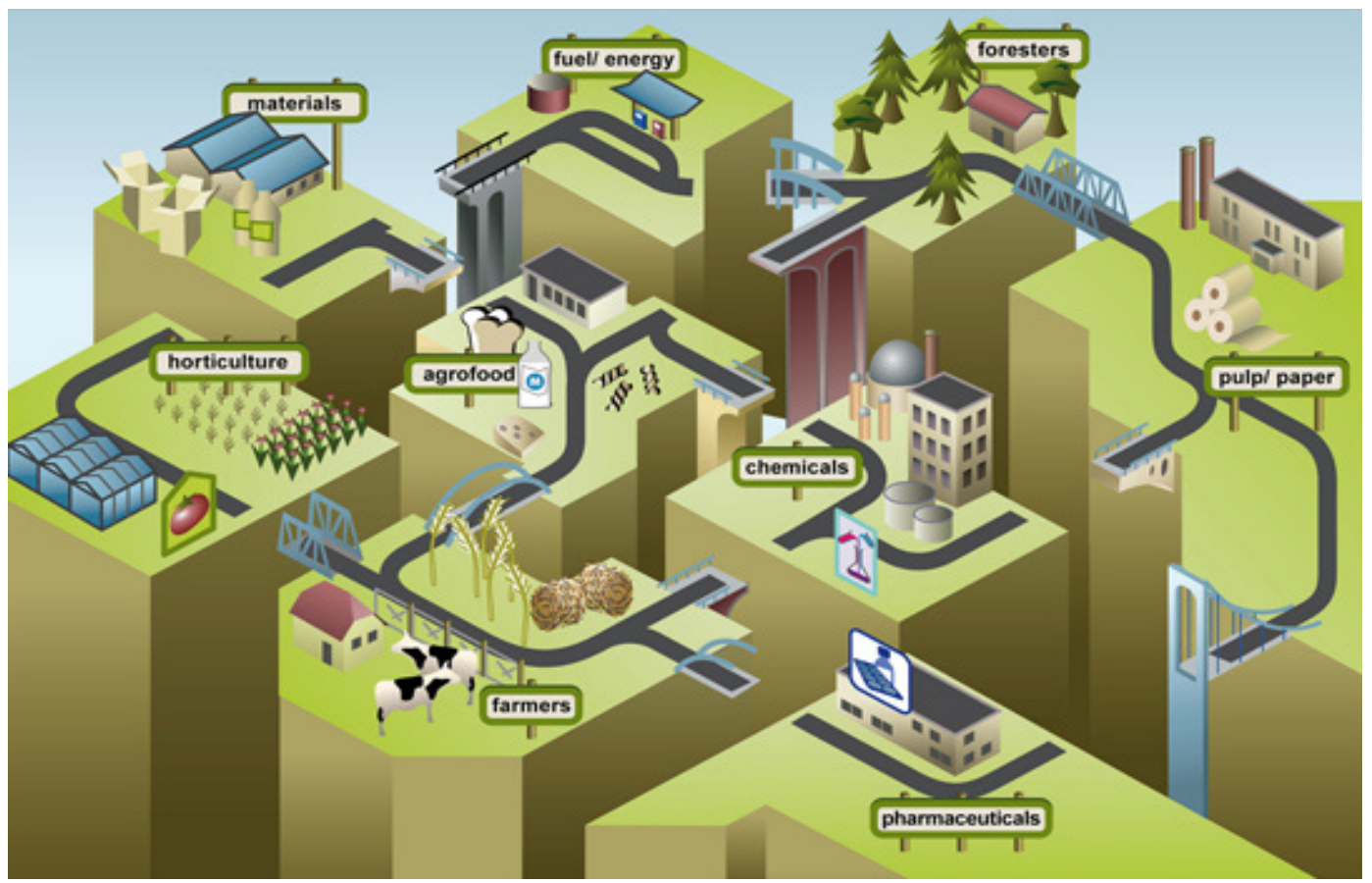

Fig. 1. Sustainable bridges are needed to built connections between different sectors of bioeconomy (from European Biofuels Technological Platform, www.biofuelstp.eu/bioeconomy ).
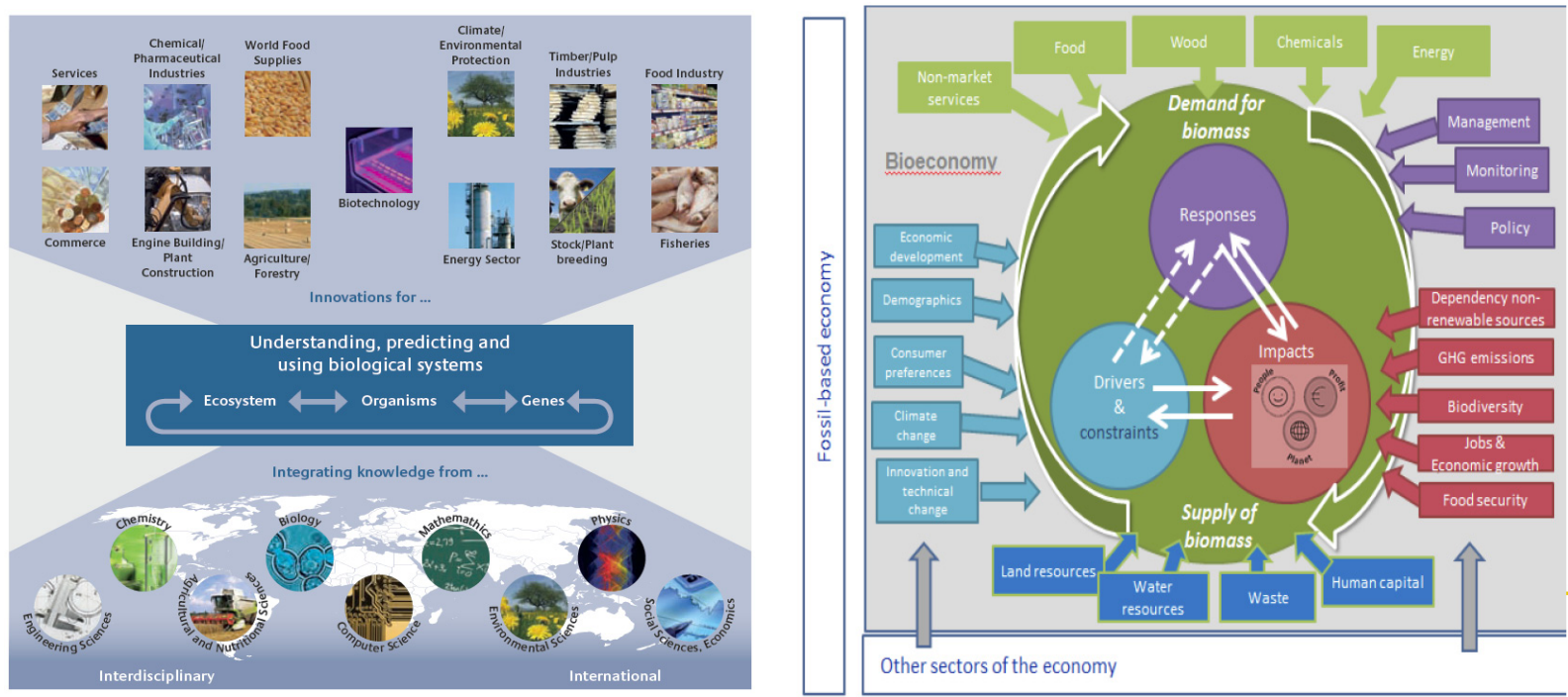

Fig. 2. Left: Knowledge-based perspective of Bioeconomy: understanding, predicting and using biological systems (ref. 20). Right: Demand and supply of biomass, 2 axes which need solutions and best responses, involve drivers/ constrains to achieve smart and added value products, with relevant impact in economy (ref. 42). 
grated bioeconomy concept, being based on six sectors: Renewable energy, Green buildings, Sustainable transport, Water management, Waste management, Land management. Green economy includes energy generation based on renewable energy to substitute fossil fuels and energy conservation, for an efficient energy use. To make such sectors sustainable, three main pillars need to be synergistically involved, namely the economic, the social and the environmental pillar. For coming decades, Europe must ensure a safe, healthy and prosperous environment for current and future generations, addressing these three major pillars which can change our life.

Greening the economy means "reconfiguring businesses and infrastructure to deliver better returns on natural, human and economic capital investments". In 2012, it was published the "Green Economy Roadmap" (ref. 23) which highlights the essential role of business in bringing solutions to common global challenges.

The Global Green Economy Index ${ }^{\mathrm{TM}}$ (GGEI) measured in 2013 (UNEP, 2011) revealed the perception and performance of 27 EU green economies and 3rd party indicators and datasets, published a white paper „Communications \& Green Economic Growth” ) revealing six areas to accelerate better communications and information exchange, green growth and cleantech investments. The GGEI considered 4 primary dimensions of a green economy at national level, from leadership and national strategies, to domestic policies and promotion of renewable energy and to green growth in home market, and green tourism.

\section{BIOECONOMY: EUROPEAN STRATEGY AND ACTION PLANS}

Recently, the European White Paper of the Bioeconomy (BECOTEPS, 2011) addressed the societal challenges and the vision for 2030, together with a set of policy recommendations to be achieved. It is the result of a collaborative effort by the experts involved in the EU Technology Platforms (ETPs) which cover the various aspects of the Bioeconomy:

1. EU Technology Platform "Plants for the Future" (Plant ETP) http://www.plantetp.org

2. EU Technology Platform "Food for Life", http:// etp.ciaa.eu/asp/index.asp

3. EU Technology Platform for Sustainable Chemistry (SusChem TP), http://www.suschem.org
4. Sustainable Farm Animal Breeding and Reproduction Technology Platform (FABRE TP), http://www.fabretp.info

5. Forest Based Sector Technology Platform (FTP), http://www.forestplatform.org

6. European Biofuels Technology Platform, http:// www.biofuelstp.eu

7. Agricultural Engineering and Technologies (AET) ManuFuture subplatform http://www. manufuture.org/manufacturing

8. European Aquaculture Technology and Innovation Platform (EATIP), http://www.eatip.eu

9. European Technology Platform for Global Animal Health, http://www.etpgah.eu

10. European Feed Technology Center (EUFETEC), http://www.eufetec.eu

The ETPs can cover different segments of the European Knowledge-Based-Bioeconomy (KBBE) and have regularly open meetings with their stakeholders, to elaborate common themes and joint priorities across the diverse sectors of EU Bioeconomy. The ETPs inputs, complement their Strategic Research Agenda (SRAs) (KBBE-2008226526 (BECOTEPS (2011). The bioeconomy strategy and action plan is presented bellow (Table 1) according to the last European vision (2012 and 2013) as well the requirements, research and economy/policy needs and aims to find the best way towards a sustainable bioeconomy (Table 2)

A coherent strategy and action plans at European level need to consider all synergies between bioeconomy-related policies and strategies in member states and worldwide, especially in emerging economies, as described in Table 3.

The European 2020 Strategy allows a crucial role of research and innovation in preparing the future challenges, coupled with CAP reform package where innovation plays a key role as well in fields like food security, bioeconomy and sustainable agriculture. The Europe 2020 flagship initiative "Innovation Union" specifies EIP (European Innovation Partnership) as a new tool for fostering innovation, as a research\& innovation-based program of collaboration across Europe, focused on „Agricultural Productivity and Sustainability" which moves the innovation from university in the agriculture field.

European Community (EU) must improve its capacity to innovate through bringing the results of research to market when compared with its 
Table 1. The bioeconomy strategy and action plan (European Commission, 2012)

\begin{tabular}{cccc}
\hline \multirow{2}{*}{ Strategy } & Ensuring food security & Creating jobs & Coherent policy \\
\cline { 2 - 4 } & Natural resource sustainability & $\begin{array}{c}\text { Maintaining EU } \\
\text { competitiveness }\end{array}$ & $\begin{array}{c}\text { Participative governance and } \\
\text { dialogue with society }\end{array}$ \\
\cline { 2 - 4 } Action plan & $\begin{array}{c}\text { Reducing dependence on non- } \\
\text { Adapting to climate changes }\end{array}$ & $\begin{array}{c}\text { New infrastructures } \\
\text { and instruments }\end{array}$ & $\begin{array}{c}\text { Investment in knowledge, } \\
\text { innovation and skills }\end{array}$ \\
\hline $\begin{array}{c}\text { Investments in research, } \\
\text { innovation and skills }\end{array}$ & $\begin{array}{c}\text { Markets } \\
\text { Enhancement } \\
\text { Competitiveness in } \\
\text { bioeconomy sectors }\end{array}$ & $\begin{array}{c}\text { Reinforced policy interaction } \\
\text { and stakeholders engagement }\end{array}$ \\
\hline
\end{tabular}

Table 2. The way towards a sustainable bioeconomy in Europe: requirements, research and economy/policy needs and aims

\begin{tabular}{|c|c|c|}
\hline \multirow{4}{*}{ Requirements } & Sustainable production & AIMS \\
\hline & Resource management & \multirow{9}{*}{$\begin{array}{c}\text { Efficient production of raw } \\
\text { materials } \\
\text { Efficient production of } \\
\text { biomass } \\
\text { Sustainability by } \\
\text { innovative, competitive } \\
\text { added-value products }\end{array}$} \\
\hline & Efficient and integrated processing of raw materials & \\
\hline & Economy coupled with socio-economy & \\
\hline \multirow{3}{*}{ Research } & Bio- and agro-sciences & \\
\hline & Engineering & \\
\hline & Economy and social sciences & \\
\hline \multirow{3}{*}{$\begin{array}{l}\text { Economy and policy } \\
\text { needs }\end{array}$} & Novel cooperation & \\
\hline & Novel technologies & \\
\hline & Novel markets & \\
\hline
\end{tabular}

Table 3. Synergies and coherence between bioeconomy related policies and strategies in Europe and worldwide

\begin{tabular}{|c|c|c|}
\hline Strategies at European level & Member states strategies & $\begin{array}{c}\text { Third countries and Emerging } \\
\text { economies }\end{array}$ \\
\hline $\begin{array}{l}\text { Research and Innovation under } \\
\text { Horizon } 2020 \text { (European } \\
\text { Commission (2012). }\end{array}$ & $\begin{array}{c}\text { Denmark, Agreement on Green } \\
\text { Growth (Danish Agency for Science, } \\
\text { 2012). }\end{array}$ & $\begin{array}{l}\text { USA (ref 30) and Canadian } \\
\text { Blueprints(BIOTECanada, } \\
\text { 2008). }\end{array}$ \\
\hline $\begin{array}{l}\text { Common Agricultural Policy } \\
\text { (PAC) and European Innovation } \\
\text { Partnership (EIP) (European } \\
\text { Commission (2011) }\end{array}$ & $\begin{array}{l}\text { Finland, Natural resource strategy } \\
\text { Sitra (2011) }\end{array}$ & $\begin{array}{l}\text { Russia (Biotech 2030, Russian } \\
\text { Technology Platform) }\end{array}$ \\
\hline $\begin{array}{l}\text { Environmental policies in Bio- } \\
\text { based economy (Staffas et al., 2013) }\end{array}$ & $\begin{array}{c}\text { Germany (Bioeconomy council, } \\
\text { Fed,2011; National Research } \\
\text { Strategy Bioeconomy 2030, 2011) }\end{array}$ & $\begin{array}{l}\text { Sweden, (Formas, Swedish } \\
\text { Energy Agency, 2012) }\end{array}$ \\
\hline Common fisheries policy & $\begin{array}{l}\text { Ireland, Developing the green } \\
\text { economy in Ireland }\end{array}$ & $\begin{array}{l}\text { OECD, The bioeconomy to } 2030 \\
\text { (OECD, 2010). }\end{array}$ \\
\hline $\begin{array}{c}\text { Energy, employment and health } \\
\text { policies }\end{array}$ & $\begin{array}{l}\text { Netherlands: Towards green } \\
\text { chemistry (BIOPOL,2009). }\end{array}$ & $\begin{array}{c}\text { Brasil and Latin America } \\
\text { Bennett and Jennings (2013) }\end{array}$ \\
\hline
\end{tabular}


Table 4. Main Priorities and actions to be followed in 2014 by the European Bioeconomy

\begin{tabular}{|c|c|}
\hline Priority & Actions to be followed \\
\hline \multirow{4}{*}{$\begin{array}{l}\text { Investments in } \\
\text { research, } \\
\text { innovation and skills }\end{array}$} & $\begin{array}{l}\text { multi-disciplinary approach by cross-cutting research, relying on more and better } \\
\text { integrated skills, innovate, adopt new } \\
\text { technologies, attract investment, and compete in new markets }\end{array}$ \\
\hline & $\begin{array}{l}\text { Better match between demand / supply of skills, helping workers and enterprises to } \\
\text { change and/or maintain the local know-how and competences. }\end{array}$ \\
\hline & $\begin{array}{l}\text { Special focus on Horizon 2020's, Public Private Partnership for the Biobased } \\
\text { Industries and the Knowledge } \\
\text { Innovation Community on Food4Future, a cross-sectoral, challenge-based approach } \\
\text { to support all steps in the research and innovation chain, translating the pre- } \\
\text { competitive research results into market-ready innovations }\end{array}$ \\
\hline & $\begin{array}{l}\text { Close the research-market gap and build an effective dialogue between industry, } \\
\text { academia and end-users. }\end{array}$ \\
\hline \multirow{4}{*}{$\begin{array}{l}\text { Stronger policy } \\
\text { coordination and } \\
\text { engagement with } \\
\text { stakeholders }\end{array}$} & Stronger policy coordination, at EU level and at national, regional and local level. \\
\hline & $\begin{array}{l}\text { developing national and regional bioeconomy strategies based on the particular } \\
\text { strengths of each country and region with its respective industries, in particular } \\
\text { SMEs, and stakeholders }\end{array}$ \\
\hline & $\begin{array}{l}\text { Continuous communication and involvement of a broad range of stakeholders in a } \\
\text { societal dialogue, to ensure legitimate societal concerns }\end{array}$ \\
\hline & $\begin{array}{l}\text { involving society at large in future debates to ensure that } \\
\text { it can evolve to become more at ease with the appliance of science in everyday life. }\end{array}$ \\
\hline \multirow{2}{*}{$\begin{array}{l}\text { Market development } \\
\text { and enhanced } \\
\text { competition }\end{array}$} & $\begin{array}{l}\text { Focus on the importance of demand-side actions, with special attention on public } \\
\text { procurement and the possibility of changing standards and regulations }\end{array}$ \\
\hline & $\begin{array}{l}\text { unlock the full potential of the bioeconomy and stay competitive in global markets, } \\
\text { European industries - especially in the more mature bioeconomy sectors - are } \\
\text { called upon to rethink their production systems, set new efficiency standards and } \\
\text { investigate new ways of producing significantly more with greater sustainability. }\end{array}$ \\
\hline
\end{tabular}

Table 5. Differences between the conventional agricultural (food / fiber oriented) and Bioeconomy-oriented systems

\begin{tabular}{l|l}
\hline \multicolumn{1}{c|}{$\begin{array}{c}\text { Conventional agricultural systems } \\
\text { (food / fiber oriented) }\end{array}$} & \multicolumn{1}{c}{ Bioeconomy-oriented system } \\
\hline $\begin{array}{l}\text { Predominance of agricultural and food } \\
\text { security policies }\end{array}$ & $\begin{array}{l}\text { Integrating environment, natural resources, food and agriculture, } \\
\text { energy and industrial development dimensions } \\
\text { Predominance of public strong } \\
\text { participation }\end{array}$ \\
$\begin{array}{l}\text { Agron investment requirements } \\
\text { oriented mostly to food production- } \\
\text { productivity-quality }\end{array}$ & $\begin{array}{l}\text { Strong participations and leadership from the private sector in } \\
\text { technology development } \\
\text { Low investment requirements }\end{array}$ \\
"Weak" intellectual property systems & $\begin{array}{l}\text { Horizontal R\&D systems ("beyond food" value chain issues) } \\
\text { "Strong" intellectual property protection systems } \\
\text { Predominance of bulk marketing and } \\
\text { logistical infra-structure, low product } \\
\text { differentiation except for quality } \\
\text { standards. }\end{array}$ \\
\hline
\end{tabular}


worldwide competitors such as China, the US, India and Brazil. Until now, EU takes too long to transform research and innovation results into marketable products (http://www.europabio. org/ ). The main priorities and actions to be followed in 2014 are presented in Table 4.

\section{BIOECONOMY AND AGRICULTURE ORIENTATIONS}

Agriculture is the main sector, connected strongly with bioeconomy, as presented by the vision document SCAR (2012). The EU strategy by the new PAC and EIP (see Table 3) reinforce strongly the role of bieconomy-oriented agriculture as presented in Table 5 ( data from Dublin stakeholders conference, 2013).

According to Table 5, one can discriminate between the conventional agricultural, food/ fiber oriented systems and the new bioeconomyoriented system, involving Know-how, innovation and technology involvement, with improved care for biosafety and consumer protection.

Recently, Rosegrant et al. (2013) reviewed the main challenges related to water and food in the bioeconomy and Henry and Trigo (2010) reflected the main aspects of the Knowledge Based Bioeconomy, from large scale experiences to instruments for rural and local development, underlying the role of innovation and sustainable development.

"Food, Agriculture and Fisheries and Biotechnology" (2007-2013) represented one of 10 thematic areas in the Cooperation programme of the European 7th Framework Programme for Research, Technological Development and Demonstration Activities. Biotechnology played an important role in addressing social, environmental and economic challenges and was recognised as a key technology enabling the transition to a green, low carbon and resource-efficient economy.

Recently, tehre were reviewed other aspects of agriculture role in the Bioeconomy worldwide. For example, Roca et al. (2004) reviewed the agricultural applications of biotechnology and the potential of biodiversity valorization in Latin America, while Potter and Loffler (2010) reported the Australian experience on applying biotechnology to design tree composition for value-added products. Mathews (2009) reported the integration of bioenergy production with agricultural demands, as an evolution from the petroeconomy to the bioeconomy, while Wield et al. (2013) describe the global challenges of biological knowledge for health and agriculture, brought by the twenty-first century bioeconomy.

\section{BIOECONOMY AND BIOREFINERY FOR} A BETTER LIFE QUALITY

Biorefinery involves cutting edge technologies to turn renewable feedstocks into bio-based products such as fuels, fibres, food, feed and chemicals, replacing their fossil fuel equivalents. Fossil fuel reserves are running out and global warming is becoming a reality, waste recycling is becoming ever more costly and problematic, and the population growth requires more energy and consumer products. In this context, bioeconomy is expected to depend heavily on renewable agroresources, generated by living organisms through the use of technology and biotechnology, but meanwhile need to reduce the environmental impact of economic growth by increasing the use of industrial and urban wastes and developing biodegradable goods (Duchesne and Wetzel, 2003).

Production and development of these new bioproducts are based on biorefinery concept: plant constituents are extracted and functionalized to produce food (or non-food products), intermediate agro-industrial products and synthons (Federal Min. Education and Research, 2012). Three major domains are focused by this strategy: to obtain molecules, materials and energy. Molecules to be used as solvent surfactants or chemical intermediates in substitution of petrol derivatives, e.g. fibers like cellulose valorized in composites (Keijsers et al., 2013). Sugars and oils are currently used to produce biofuels like bioethanol or biodiesel, but second-generation biofuels will use lignocellulosic biomass as raw material. Plant lipids can be used to produce a large diversity of products like solvents, lubricants, pastes or surfactants (Muller et al.,2012). The main requirements for the development of a bioeconomy for chemicals was recently reviewed by Dubois (2011). Industrial biorefinery will be linked to the creation of new processes based on the twelve principles of green chemistry (clean processes, atom economy, renewable feedstocks, etc.). White biotechnology, involving biotransformations (by enzymes or microorganisms) and fermentations will be involved in ,industrial metabolism” (Octave and Thomas, 2009; Viaggi and Cuming, 2010). 
Plant and food Biotechnologies for nonhealth applications have received a considerable attention in former European FP7 projects , including 61 projects on industrial, marine, plant, environmental and emerging biotechnologies representing a contribution of 262.8 million EURO from the European Commission. Outlooks of the research, technological development and demonstration activities in biotechnology, as well the biosecurity aspects in the policy context were recently reviewed (Cichocka et al, 2011; Shepard, 2011; Clarke and Zhang, 2013). An excellent example of the European projects related to Bioeconomy is SAT-BBE Project, which aims the design of an analysis tool useful to monitor the evolution and impact of Bioeconomy, recently published as a report- Overview of the Systems Analysis Framework for the EU Bioeconomy (Van Leeuwen et al., 2013)

\section{EDUCATION, RESEARCH \& INNOVATION IN BIOECONOMY: CONVERTING THE VISION INTO REALITY}

Education and training is a "sine-qua-non" condition of progress and a key-sector for bioeconomy progress, which aims the training of young generations of professionals to be directly involved in the integrated Bioeconomy activities. Actually, the European companies related to Bioeconomy have problems for recruiting appropriate, skilled people, either due to a poor image of this sector or unknown available opportunities among young people. Employers need people with university education and/or appropriate sector specific training but also with interdisciplinary knowledge. Special attention is needed for the next generation of good technicians and skilled manual workers, researchers, entrepreneurs, managers and traders. Encouraging the mobility across Europe of young researchers, entrepreneurs, students and skilled staff from industry, as well the cross-recognition of qualifications between EU States, by International training and education programs (including life long learning) will bring advantages in long term.

Considering the profile of former Agriculture oriented universities in Europe (called Life Science universities nowadays), different specific sectors of green economy are approached: renewable energy (biofules), land \& water \& waste management, biorefinery, food and nutrition, animal health and consumer protection, etc. The research competences of university RTD (Research\& Technological Development) units and projects are complemented with their abilities to support innovations and give consulting to farmers and companies, as well to evaluate the economic feasibility for future business in this area.

Among the first Actions to take in European Community was a coherent "Education Action Plan" covering all sectors, having inputs from all relevant stakeholder groups. This plan includes: the information of national education authorities and universities about the future needs of the Bioeconomy for a well-qualified workforce.

The Bioeconomy Panel of Experts, recently constituted by European Commission includes representatives of all stakeholders involved in Bioeconomy strategy (http://ec.europa.eu/research/ bioeconomy). This panel supports interactions for advices in implementation of the EU strategy, suggestions for European joins actions and measures, monitoring and evaluating the progress. The experts represent EC services (DG Research, DG Agri, DG Environment, etc), member states representatives of Ministries, stakeholders representatives (research and education, farmers, industry associations, NGOs, etc.). The panel offer an open dialogue (1) between policy makers, researchers, stakeholders, civil society, expertise through ad-hoc hearings (2) from working/ advisory groups and committees SCAR, AG for LMI on bio-based products, EIP, PPP (Publicprivate partnerships) as well by the activity of Bioeconomy observatory (3) focused on capacity mapping, technology watch, market monitoring, bioeconomy policy outlook. The PPP programs are yet launched and can offer important opportunities of collaborations between universities, research institutes and companies (SME- small middle entreprises ) or big companies (which co-finance such strategic projects) (Hodges, 2012).

In February 2012, the European Commission published a Communication "Innovating for Sustainable Growth: A Bioeconomy for Europe" (ref.18) which presents the Strategy for Europe and an Action Plan which includes the establishment of the Bioeconomy Observatory that allows the Commission to regularly assess the progress and impact of the bioeconomy. In March 2013, the European Commission's Joint Research Centre (JRC) started a three-year project to set up the Bioeconomy Observatory, to collect and 
disseminate data and information regarding the three key pillars highlighted in the EU Bioeconomy Strategy: Investments in research, innovation and skills (A), reinforced policy interaction and stakeholder engagement (B) and enhancement of markets and competitiveness in bioeconomy (C).

Marie Curie fellowship Programs will be also continued, with greater encouragement for young moving from universities to industry and then return to academia, as well exchanges between academia/industry and the media, and academia/ industry and policy/regulatory bodies. Universities should promote the concepts of being inventive and taking justified risks in order to stimulate entrepreneurship (BECOTEPS (2011). Small-scale processing of biomass for biorefinery is one of main research areas in universities as well biorefinery (Bruins and Sanders, 2012).

The multiple and cross sectorial involvement by the education-research-innovation chain, from food/feed, to bio-based fuels, bio-based materials, bio-based chemicals is presented in Table 6 .

\section{CONCLUSION}

According to the European vision and strategy for 2030, bioeconomy will be able to deliver a sustainable growth to address societal challenges (Langeveld et al, 2010; BECOTEPS, 2011). Key messages about the bioeconomy strategy in Europe, as presented recently in Dublin Conference (Bioeconomy stakeholders conference, 2013) refer to multiple aspects which will characterize the future of Europe. As pointed out, the main features need to be:

Diversity: multidimensional in nature, involving traditional sectors and a broad and diverse range of biological resource inputs, conversion processes and end uses. Diverse range of stakeholders, such as farmers, fishermen, agribusinesses, food processors, waste handlers, advanced bio-material manufacturers, bio-pharmaceuticals, researchers, educationalists, policy-makers, bioenergy providers, NGOs and civil society need to involve for a coherent development.

Flexibility: allowing each country, region, industry and stakeholder to play to their strengths

Table 6. Multiple and cross sectorial involvement by education-research-innovation chain from food/feed, to biobased fules, bio-based materials, bio-based chemicals

\begin{tabular}{|c|c|c|}
\hline Research areas & Aims & Scientific and technological areas \\
\hline $\begin{array}{c}\text { Studies on soil, water, } \\
\text { nutrients } \\
\text { Plant biomass and } \\
\text { technologic performance }\end{array}$ & $\begin{array}{l}\text { Improvement of quality and quantity of } \\
\text { biomass } \\
\text { Resource management ( soil/water/ } \\
\text { nutrients) } \\
\text { Improved production systems under } \\
\text { global change }\end{array}$ & $\begin{array}{c}\text { Agrosciences, Plant sciences and } \\
\text { genetics, Geosciences, Genetics, Ecology }\end{array}$ \\
\hline Food and Nutrition & $\begin{array}{l}\text { Improving nutrition and health, quality } \\
\text { of life }\end{array}$ & $\begin{array}{l}\text { Process engineering, Food science and } \\
\text { technology, Nutrition and toxicology }\end{array}$ \\
\hline $\begin{array}{l}\text { Chemicals and } \\
\text { pharmaceuticals }\end{array}$ & $\begin{array}{l}\text { Chemicals, pharmaceuticals and proteins } \\
\text { from renewable resources } \\
\text { Whole cell, hybrid catalysts from } \\
\text { combined enzymes and chemicals } \\
\text { Synthetic biology for novel products for } \\
\text { chemical industry and pharma (Philp et } \\
\text { al., 2013) }\end{array}$ & $\begin{array}{l}\text { Structural biology, Biotechnology, } \\
\text { Chemistry, Pharmacy }\end{array}$ \\
\hline $\begin{array}{l}\text { Fuels and renewable } \\
\text { energy }\end{array}$ & $\begin{array}{c}\text { Extraction and transformations of } \\
\text { intermediates (biorefinery), product } \\
\text { design }\end{array}$ & Informatics/robotics/engineering \\
\hline $\begin{array}{l}\text { Bioinformatics and } \\
\text { knowledge management }\end{array}$ & $\begin{array}{c}\text { Environment and resource economy } \\
\text { Management of process and value chains } \\
\text { Consumers acceptance }\end{array}$ & $\begin{array}{c}\text { Systems biology, Economy, Social and } \\
\text { Political Sciences, Communication and } \\
\text { media }\end{array}$ \\
\hline
\end{tabular}


by focusing on the part(s) of best potential, in order to optimise their benefits.

Coherence: all actors along the value chain must work together at various levels in a coherent manner if it is to achieve its full potential. This applies to all three pillars: scientific and technological research disciplines (1), inter-DG/ ministry/region working arrangements (2) and public-private partnerships (3). At EU member state level, synergies between different relevant policies should be maximised to give coherent messages to stakeholders and industry.

Innovation: to find new ways to connect knowedge to technology, opening up far beyond a purely technology-based approach to innovation.

Skilling/Reskilling: mixing the existing skills and occupations (e.g. farming, fishing, etc.) with new high- and low-tech skills in a range of biorefining and bioprocessing technologies, with implications for educational curricula which will need to be re-engineered to meet the demands of the bio and green economies of the future.

Sustainability in 3 dimensions: economic, social a: moving towards a low-carbon, green economy where consumers are increasingly focusing on health, well-being and sustainable food production. Implies smart and innovative solutions and technologies to increase productivity and guarantee profitability for all actors/enterprises and in particular SMEs.

Awareness and Communication: replacing the lack of clarity about bioeconomy by adequate communication to consumers, in simple terms, using a simple language, standardised, clear and easily understandable, explained by an interactive and iterative dialogue.

Security: the stability and efficient development of Europe's bioeconomy is of high importance, not only for food security, but the adaptations required to balance an economic use of biological resources, respecting meanwhile the conservation of the environment.

Finally, we can assume that bioeconomy needs coherent and integrated policy directions in Europe towards relevant research areas, within each sector and by encouraging multi-disciplinary programs, innovation and knowledge developments, to reach the commercialization stage, making entrepreneurship a desirable career option. Universities are able to provide skilled specialists through secondary and tertiary education, under innovation- friendly regulatory framework to balance risks and benefits. The good communication with the public by R\&D projects is compulsory, to ensure societal appreciation of research and innovation related to bioeconomy.

\section{REFERENCES}

1. BECOTEPS (2011). The European Bioeconomy in 2030, Delivering Sustainable Growth by addressing the Grand Societal Challenges, www.becoteps.org, http://www. epsoweb.org/file/560.

2. Bennett, D. J. and Jennings, R. C. (eds.) (2013). Successful Agricultural Innovation in Emerging Economies, Cambridge University Press .

3. Bioeconomy Council (2011). Bio-economy Innovation, Bio-economy Council Report 2010, Bio-economy Research and Technology Council (BOR), Berlin

4. Bioeconomy Stakeholders Conference (2013). Bioeconomy in the EU: achievements and directions for the future, Dublin, 14-15 February 2013.

5. BIOPOL (2009). Final Report of the assessment of biorefinery concepts and the implications for agricultural and forestry policy (BIOPOL) project. www.biorefinery. nl.biopol.

6. BIOTECanada (2008). The Canadian Blueprint: Beyond mouse and mountains, how we can build the world leading bio-based economy.

7. Biotech 2030, Russian Technology Platform "Bio-industry and bio-resources", Moskow, 2012.

8. Bruins, M. and Sanders, J. (2012). Small-scale processing of biomass for biorefinery, Biofuels Bioproducts and Biorefining 6 (2):135 - 145.

9. Cichocka, D. et al. (2011). European Union research and innovation perspectives on biotechnology, J. Biotechnol. 156: SI 382-391.

10. Clarke, J. L. and Zhang, P. (2013). Plant biotechnology for food security and bioeconomy, Plant Molecular Biology 83: 1-3.

11. Danish Agency for Science (2012). Technology and Innovation, Strategic Platforms for Innovation and Research: The bio-based economy, Copenhagen.

12. Diaz-Chave Rocio A. (2010). Assessment of existing socioeconomic principles, criteria and indicators for biomass production and conversion. www.globalbiopact. eu.

13. Dubois, J.L. (2011). Requirements for the development of a bioeconomy for chemicals, Curr. Opinion Env. Sustainability 3:11-14.

14. Duchesne, L. C. and Wetzel, S. (2003). The bioeconomy and the forestry sector: Changing markets and new opportunities. Forestry Chronicle 79: 860-864.

15. EU SCAR (2012). Agricultural Knowledge and innovation systems in transition- a reflection paper. Brussels.

16. European Commission (2005). New perspectives on the knowledge based bio-economy: A conference report, Brussels. 
17. European Commission (2011). Sustainable food consumption and production in a resource constraint world, $3^{\text {rd }}$ SCAR foresight exercise.

18. European Commission (2012). Innovating for a sustainable growth, A bioeconomy for Europe.

19. European Commission (2013) Bio-based industries, towards a public-private partnership under Horizon 2020 ? Brussels.

20. Federal Min. Education and Research, Biorefineries Roadmap as part of the German Federal Government action plans for the material and energetic utilisation of renewable raw materials Bonn, Berlin, 2012.

21. Federal Min. Education and Research, National Research Strategy for Bioeconomy 2030-Our route towards a biobased economy, Bonn, Berlin, 2011.

22. Formas, Swedish Energy Agency and Villanova, Swedish Research and Innovation Strategy for a Bio-based Economy, 2012.

23. Green Economy Roadmap (2012). Best practices and calls for collaborations, International Chamber of Commerce.

24. Henry, G. and E. J. Trigo (2010). The Knowledge Based Bioeconomy at Work: From Large Scale Experiences to Instruments for Rural and Local Development: Innovation and Sustainable Development in Agriculture and Food www.isda2010.net.

25. Hodges, M. (2012). The politics of emergence: Publicprivate partnerships and the conflictive timescapes of apomixis technology development, Biosocieties, 7: 23-49.

26. Keijsers, E. R. P. et al. (2013). The cellulose resource matrix. Carbohydr. Polymers 93: S9-S21.

27. Langeveld, J. W. A. et al. (2010). Development Perspectives of the Biobased Economy: A Review. Crop Science 50:S142-S151.

28. Mathews, J.A. (2009) From the petroeconomy to the bioeconomy: Integrating bioenergy production with agricultural demands. Biofules bioprod. \& Biorefining 3: 613-632.

29. Muller, M.M. et al. (2012). Rhamnolipids-Next generation surfactants? J. Biotechnol. 162: 366-380.

30. National Bioeconmy blue print (2012) Washington, USA

31. Octave, S. and Thomas, D. (2009). Biorefinery: Toward an industrial metabolism, Biochimie, 91: 659-664.

32. OECD (2010). The Bioeconomy to 2030: Designing a Policy Agenda. OECD International Futures Project, OECD, Paris, France.
33. Philp, J. C. et al. (2013). Synthetic biology, the bioeconomy, and a societal quandary. Trends in Biotech. 31: 5-8.

34. Potter, S. and Loffler, S. (2010). Applying biotechnology to design tree composition for value-added products: a minireview, Australian Forestry 73: 191-197.

35. Roca, W. et al. (2004). Agricultural Applications of Biotechnology and the Potential for Biodiversity Valorization in Latin America and the Caribben AgBioForum, 7(1\&2): 13-22.

36. Rosegrant, M. W. et al. (2013) Water and food in the bioeconomy: challenges and opportunities for development, Agric. Economics 44: 139-150.

37. Sheppard, A. W. et al. (2011). Biosecurity as an integral part of the new bioeconomy: a path to a more sustainable future, Curr. Opinion Env. Sustainability 3: 105-111.

38. Sitra (2011). Sustainable Bio-economy. Potential, Challenges and opportunities in Finland.

39. Staffas, L. et al. (2013). Strategies and Policies for the Bioeconomy and Bio-Based Economy: An Analysis of Official National Approaches Sustainability 5:2751-2769.

40. Trigo, E.J., G. Henry, J. Sanders, U. Schurr, C. Ingelbrecht, C. Revel, C. Santana and P. Rocha (2013). Towards bioeconomy development in Latin America and the Caraibbean, Bioeconomy Working Paper, nr. 2013-01, EU ALCUE KBBE.

41. UNEP (2011). Towards a Green Economy: Pathways to Sustainable Development and Poverty Eradication, www. unep.org/greeneconomy.

42. Van Leeuwen M., H. Van Meijl, E. Smeets and E. Tabeau (eds), SAT-BBE Project Report, Overview of the Systems Analysis Framework for the EU Bioeconomy, LEI Wageningen UR, Den Haag, NL, 2013.

43. Viaggi, D. and Cuming, D. (2010). Developing improved tools for the economic analysis of innovation in food biotechnology: a review of past research and prospective developments, J. Biotechnol. 150: S68-S69.

44. Wield, D. et al. (2013). Twenty-first century bioeconomy: Global challenges of biological knowledge for health and agriculture, Science and Public Policy 40: 17-24.

45. You, C. et al. (2013). Enzymatic transformation of nonfood biomass to starch, Proc. Natl. Acad. Sci. USA, 110:71827187. 